\title{
Teaching English Language Courses for Tourism and Hospitality Purposes (A Study of Graduates Workplace Needs)
}

\section{Dr. Hussam Ahmad Qaddumi*}

Assoc Professor in TEFL, PhD in TEFL, Faculty Member Al Istiqlal University, Jericho, Palestine | Corresponding Author Email: dr.hussamqadomi@ pass.ps

\section{Dr. Khaled Mahmoud Masood}

Assistant Professor in English language, $\mathrm{PhD}$ in English Language, Head of English Department Al Istiqlal University, Jericho, Palestine | Email: dr.khaled@ pass.ps

\section{Dr. Hassan Ahmad Qaddumi}

Assistant Professor in Applied Geography, $\mathrm{PhD}$ in Applied Geography, Faculty Member Hebron University, Hebron, Palestine | Email: haalkadumi@yahoo.com

\section{Dr. Samir Mohamad Rammal}

Assistant Professor in Translation, $\mathrm{PhD}$ in Translation, Faculty Member, Birzeit University, Palestine |Email: srammal@brzeit.edu

\begin{abstract}
When taking into account Palestinian tourism sites, mastering language English for instance is a prerequisite for serving and offering tourism services in tourist places such as Bethlehem, Jerusalem, Jericho and Hebron after graduation. In Palestine, English for Specific Purposes especially in hospitality and tourism purposes has not been given much investigation in research. Globally, English language is used as a medium of communication in contexts such as hospitality, travel, and tourism. This study examined how English language is used to prepare tourism and hospitability learners who anticipate serving in Palestinian tourism sites.
\end{abstract}


The data indicated that the learners' perceptions of the courses offered in English are not consistent with their aspirations and perceived academic English language needs, and their response to how they perceive the importance of English language needs was moderate. Based on these findings, the study suggests restructuring these courses and reconsidering the adopted teaching methods to help learners receive proper instruction geared towards intended learning outcomes and meets their future workplace needs. For future studies, it is recommended that quantitative and qualitative researches are needed to be carried out to analyze the actual needs of undergraduate students to the English language in programs hotel management and tourism.

Keywords: Tourism, Curriculum, EFL, Hospitability, Workplace.

\section{Introduction}

The English language is commonly used in many disciplines such as the tourism and hospitability industry. Learning foreign language skills is an integral part for people, who work in the tourism sector, tasks as it is the means of communication with tourists. It also helps in understanding their cultural differences and increasing the quality of the tourism industry (Sindik \& Božinović, 2013). According to Leslie \& Russell (2006), being able to use foreign languages is an integral part for those who work in the fields of hospitality and tourism (CANAS \& Pérez, 2015). The reason is that it is the means for having communication with foreign tourists and understanding cultural differences (Zahedpisheh, Abu Bakar \& Saffar, 2017). Mastering a foreign language is obvious in the field of tourism and hospitality. Besides, communicative language ability is also significant to develop intercultural competence (Tziora, Giovanis, \& Papacharalabous, 2016). Knowing foreign languages is necessary to learn cultural awareness (Kluge, 1984). Increasing cultural awareness is a means to see both the positive and negative aspects of cultural differences (Pokhilko, 2019). In the process of learning a new language, it is important to be aware of its cultural aspect(s), because knowledge of other cultures helps a learner to learn a certain language and to assess the cultural values of that language (Choudhury, 2014; Prachanant, 2012).

According to the Palestinian Central Bureau of Statistics, 2017 the contribution of the tourism sector to the Gross Domestic Product (GDP) cumulated to \$ 2.5 million.

Although Palestine has a tremendous confiscated number of antiquities and many resorts, it annually attracts millions of tourists from all over the world (Ma'an News Agency, 
2016).Tourism is not only a material contributor that creates jobs and improves income levels, but it also contributes to bridging the gaps between cultures and societies (Adiyia, Vanneste, \& Van Rompaey, 2016). It is also a media platform that brings to the world the cultural dimensions and identity of the Palestinian people.

According to the Palestinian Central Bureau of Statistics, Palestine received $(502,850)$ thousand tourists who visited the West Bank and Jerusalem in 2017. Although the current political instability in Palestine has a huge negative effect on the hospitability and tourism sector, experts in the field of hospitability and tourism in Palestine will return quickly again. In Palestine, the tourism and hospitability guides use English to deal and communicate with visitors and tourists who come to visit Palestine from all over the world. It is natural, therefore, to find English taught as a compulsory subject at universities in Palestine. According to the Palestinian Ministry of National Economy and Palestine Trade Center (2019:40), 'there is an overall need to upgrade the tourism curricula and to enhance the language skills (English as well as other languages), and to provide graduate learners at early stages of education with practical experience in the industry.' No study has been conducted to examine the courses of English language which are offered to graduates from higher education institutions and to unveil learners' views on them. The present research will bridge this gap by studying how the English language is being taught for tourism and hospitality purposes in Palestine and examining learners' satisfaction with the taught courses. An overview of tourism and hospitality in Palestine is provided in the next section.

\section{A. HOSPITALITY AND TOURISM SECTOR IN PALESTINE}

Tourism in Palestine is an important arena for establishing the Palestinian national identity. Palestine is the most important destination in the plans and programs of tourists' delegations from around the world. Tourism started from Palestine as religious tourism. The Ministry of Tourism and Antiquities, since the beginning of the year, the number of tourist arrivals and the number of nights spent in Palestinian hotels has increased significantly. The number of visitors to tourist and archaeological sites in the first half of 2018 reached 1.48 million, 5\% compared to the same period of 2017, while Palestinian hotels registered 750 thousand overnight nights, an increase of 25\% over the same period in 2017 (Ma'an News Agency, 2016). This is a result of the real partnership between the Ministry of Tourism and Antiquities and the activities of the Palestinian private tourism sector, 
in addition to the active promotional campaign in the world of tourism markets to attract tourists to Palestine. Palestine participates in several international tourist exhibitions. This is essential to stabilize the Palestinian presence in this international arena and to market Palestine as an independent destination. Through Palestinian tourism programs based mainly on the use of Palestinian tourism facilities Palestinian cities and hotels. The Ministry of Tourism and Antiquities seeks to make the experience of the tourist in Palestine a rich experience(This week in Palestine, 2012). This year, the World Tourism Organization (WTO) has adopted the theme of "Tourism and Digital Transformation" to highlight the importance of technological developments and innovations in the continued growth as the sustainability of the tourism sector increases and will highlight the need to invest in digital technologies that can create the environment for innovation and entrepreneurship in tourism. Minister of Tourism and Antiquities in Palestine has adopted the slogan of digital transformation in the field of tourism for some time. The Ministry of Tourism and Antiquities has worked on developing Palestinian tourism through several tourist information centers in all Palestinian cities and developed the capabilities of workers in the Palestinian tourism sector (World Tourism Organization, 2017).

\section{B. THE CASE OF TOURISM AND HOSPITALITY IN PALESTINE}

Hospitality and tourism education in Palestine started in 1973 when one higher education institute was founded. In 1973, four -years period which learners should enroll in the higher institute to gain a Baccalaureate degree in Hotel Management. Different degrees were also offered such as the degree or diploma in Hotel Management, Travel Agency Management, and Tour Guides. The mission of these programs is to prepare highly qualified workers for joining the police forces and other sectors private or public who work for tourism. These programs provide learners with a variety of courses, preparation, and training in the field of hospitality, tourism, and management. Learners who major in the degrees such as Hotel Management and Tourism should choose one foreign language i.e. French or Spanish. Further, they should complete 18 credit hours in the selected language. Thirty-four credits are university requirements. Concerning the courses taught to learners who major in Hotel Management, they should complete 79 credits in total. Only one English language course is offered. After successfully passing the 131 credits in the four academic years, learners graduate with a degree in Hotel Management and Tourism. The language used in teaching the courses is Arabic. 
It is very important to be motivated to master the language and be fluent in the language for professional purposes if you want a job in the field of hospitality and tourism. Also, employees must become advanced users of English for tourism purposes (Cravotta, 1990).

Arabic is the medium of instruction in higher education institutes so learners must only study two main English courses one course in the first semester and the other on the second. Learners are required to enroll in 8 courses of English language divided into four years. These courses are English Language Skills I which involves reading skills that are important for academic purposes, English Language Skills II course focuses on the learners' reading, writing, listening, and speaking skills that learners must master at the university level and English Language Skills III in which learners develop and implement the sub-skills such as reading, writing, listening and speaking. No previous studies have been conducted on the way English is taught to learners who seek a degree in tourism and hospitality in Palestine. This study also examines whether English language preparation courses meet the learners' actual needs and requirements for their future workplace.

\section{RELATED STUDIES}

In Palestine, the process of English language teaching for hospitality and tourism purposes has not been given much investigation in research. Internationally, the usage of the English language as a medium of communication in hospitality, travel, and tourism contexts has been given great care. Comparing researching tourism English in Palestine with Arab countries and international ones, we find for example some studies tested the impact of these courses in fostering tourism learners' language abilities (Akyel\&Yalcin, 1991; Fuentes, 2004; Lo \&Sheu, 2008; Luka, 2009), other studies investigated language needs of learners (Afzali\&Fakharzadeh, 2009; Choi, 2010; Prachanant, 2012; Russell \&Leslie, 2005; Erazo, Ramírez, Encalada, Holguin \&Zou, 2019).

In the context of the Arab World, very limited numbers of studies have been carried out. For example, Abdel Ghany\& Abdel Latif (2012) studied how undergraduate learners of tourism and hospitality in Egypt are prepared. Moreover, the study compared the perceptions of teachers and learners. Results revealed that learners' perceptions of the services which are provided for them to be prepared in the English language are different from those of their teachers. The study also mentioned problems in the instructions of the English language. 
In a study conducted in a similar context, Zayed (2009) investigated the effectiveness of implementing active and proactive reflection in fostering tourism learners' English oral skills. The results of the study showed that the group which was subject to the experiment performed better than the control group in total performance quality, oral performance, and language awareness.

\section{Present Study}

This study aimed to investigate English as a language of instruction to undergraduate learners at the Institute of Hotel Management and Tourism in Palestine and to test if this way of teaching is essential for their future jobs or not. The study addressed the following two questions:

1. How is the English language delivered to learners' at the Institute of Hotel Management and Tourism in Palestine?

2. Based on the views of learners enrolled in this program, are the English language preparation courses important to learners' actual future workplace? Are they satisfied with the adequacy of these courses?

\section{Methodology}

To answer research questions, the present study gathered data about the English language courses which are delivered for the learners who enroll in the Institute of Hotel Management and Tourism in Palestine. The researchers collected the data using both qualitative and quantitative methods. Because it is a flexible tool, the researcher implemented the semi-structured interviews. Also, the interviews help to comprehend the research. Interviews were conducted with eight student participants and the questionnaire was distributed to 70 learners. A random sample of learners was selected. In the beginning, the researchers clarified the purposes of the study to the student participants, and they indicated that they agree to participate voluntarily in the study. The researchers interviewed male and female learners who participated in the study. Out of the ten interviewed participants, five were males and five were females. Seventy learners completed the questionnaire, 34 were males and 36 were females.

The interview questions focused on how the learners learn, and how they are taught English skills in courses of English series I, II, and III. The student participants were also asked to complete a questionnaire to examine whether English courses are important to their future workplace. 
Before the researchers conducted the interviews with the participants, copies of the English language courses taught were checked to deduce the interviewees' questions. All the interview meetings were conducted in January 2019. The language of the interviews was Arabic because it is the mother tongue of the student participants. No student was obliged to be interviewed although it is a police academy and regulations allow us to do so, we did not. Every student was individually interviewed for 35-45 minutes. To transcribe and analyze the interviews, all the interviews were recorded.

\section{Results of the Study}

In this part, the researchers illustrate a description of the English language textbooks used. Also, how the English language is taught and assessed at the institute is investigated.

\section{A. Teaching Materials Used in Hotel Management and Tourism Program}

The book of English, drills, and testing which are used in the instruction of English to hotel management and tourism were investigated. Our investigation revealed that the textbook the University uses with learners depends, mainly, on reading and writing. The textbooks are: (a) Making Connections, (b) Skills for Effective Writing, and (c) Longman Academic Writing Series. These textbooks are English language textbooks. Each of these textbooks mainly included materials that the teachers of English for general purposes materials use. Moreover, the selected textbooks do not contain drills of listening skills and speaking skills. That is, the areas such as grammar and vocabulary, writing, reading, drills were focused on. After we analyzed the textbooks it was obvious that the majority of tasks learners did consolidate the writing skill and the structures, whereas there were no related tasks to the skill of listening or speaking.The textbooks contained general topics rather than topics related to communication in the tourism context in Palestine.

\section{B. Emphasized skills}

The student participants revealed salient features about the language skills their English language teachers emphasized. Most of the interviewed learners showed that English language teachers emphasized reading skills, grammar, writing, hospitality, and tourism expressions.

Based on learners' views, teaching to improve their language skills such as communication with foreigners functionally, speaking or listening skills is missing. 
The participants asserted that most of the time, in English language classes, was a matter of translation of such reading texts into their mother tongue, Arabic. Concerning listening and speaking skills, they were overlooked. The main focus of practice was on retaliating grammar drills. Teachers of the English language, in this program, usually use the traditional method. Learners' role was discarded, and their language teaching environment was a teacher-dominated rather than students-centered. This means the teacher was dominating the scene, teaching and explaining all the time. However, learners did not produce language. They copied all the time. Some student participants' interviews excerpts indicate the way the English language is taught:

\section{Student 5:}

"We do not usually read, we just pay attention and listen to our English language teacher while he/she is reading for us loudly the passages and translating the new expressions into Arabic, then the language teacher asks learners to answer the questions in their copybooks. We don't normally speak, discuss or listen to a recording or watch a video. I feel that we should take more courses."

Student 3:

"We don't have the chance to speak or practice listening to the English language during class time. The teacher is always talking all the time. We don't use speaking to communicate with our classmates during classes. We are passive, we don't practice English. The courses they give us are not enough."

\section{Student 7:}

"We had never practiced pair work activity in our English class which is included in the book; we have speaking and listening drills in the textbook but they are skipped. We are not required to study speaking and listening drills. Mostly, we practice grammar and how writing."

\section{Learners' Perceptions of Their Actual Needs}

In developing an ESP material to be taught in a course, for example, English for Tourism two components must be included: (a) deciding on the needs of learners before starting to teach the language and learners' achievement should be tested (Razika, 2017). Language teachers should conduct needs analysis before course design to determine the Intended Learning Outcomes that should be met and the skills of English language which are potential to be developed, 
(b) to change or edit the syllabus based on the learners' actual needs (Abdalla, \& Mohammed, 2016;Akyel, \&Ozek, 2010;Alastal, 2012; Ali, \&Salih, 2013; Bosuwon, \& Woodrow, 2009; Chostelidou, 2010; Chen, Chang \& Chang, 2016; Elsaid Mohammed, 2018; Eslami, 2010; Mohammadi, \&Abdi, 2014; Javid, 2011; Martins, 2017;Serafini, 2015; Ulla, \&Winitkun, 2017; Ulum,2016 ).

\section{Checking the Testing Methods Used in Such Courses}

After asking the department to provide the researchers with copies of the Mid-term and Final examinations, it is generally divulged that learners sit for only written exams, whereas oral exams and presentations were missing from the assessment procedure. That is, oral testing or peer assessment is not used by the language teachers. Generally, analysis of the exams used by the language teachers showed that these exams usually are prepared to comprise (1)vocabulary: which intends to assess learners' writing full sentences using the vocabulary, fill in the spaces, and fill in the spaces all related to tourism. (2) Reading: asks learners to read passages about tourism and answer comprehension questions. (3) There should be testing for language testing to assess learners' knowledge of learned structures; also (4) writing: this part measures learners' ability to write a composition of 120 words about one topic which is related to tourism and hotel management. Altogether, the learners' indications of how the language is delivered and tested in this program reveal great restrictions in the language courses provided to them. Serious problems that may draw the attention to the fragility of teaching English as a Foreign language (EFL hereafter) to the learners in this program are the absence of teaching speaking and listening skills (i,e, communication skills with special emphasis on English for Tourism), using different ways of assessments and assessing learners' needs when designing their syllabuses.

After asking learners about their English language courses, the learners' perspectives revealed two important points: The reasonableness of English courses they take and their real needs for such English courses.

\section{E. Reasonableness of English Courses}

Generally, the semi-structured interviews with learners indicated that those who are registered in this program are not happy with the number of English courses and with the instruction, their teachers offer, too. 
When we asked them if they were satisfied with the instructions and the taught courses, all learners showed passive feelings because what they learned didn't meet their future workplace needs. Another reason for this feeling of discontent was that although the textbooks contained communicative drills, their language teachers neglect them.

\section{Student1:}

"Learning functional and situational English is more relevant to my work. I want to master communication so as not to be afraid of foreigners. This I need. I think teachers should focus more on the speaking activities because the exposure to listening in our courses is not enough to develop our listening and speaking skills. Accordingly, it won't be that much beneficial in our future workplace. The English language course didn't support me in the English language skills that I sought to acquire to be able to function properly in my work in the field of hospitality and tourism in the future."

\section{Student 2:}

"Usually, in our English classes, the main focus is on reading. I think the teaching of reading will not benefit in developing my conversation /communication in English especially when we talk to tourists. I need to communicate with visitors in English in the historical sites. I think listening and speaking are more important for my future workplace."

Student 4:

"Frankly, our language teachers focus on the reading skill. Writing is also a core of our English course. The number of English courses taught is not enough. Learners most of the time attend language courses at the British Council."

Student 6:

"No one can deny we acquired new vocabulary, practiced grammar and we were exposed to the common errors in writing, structures, and some pronunciation by our teachers; but there our teachers do not emphasize the skills of communication, speaking, and listening. Accordingly, I and my colleagues have initiated self-studying English listening and speaking. We also enrolled in an English conversation course run by international institutions. This is because we believe when we may master communication skills, speaking and listening that will help us in our future workplace." 


\section{Student 8:}

"To develop my language level, I should register for an English language training course after I finish my study. Frankly, I don't think that the English language course the program provides me with is not going to be that much helpful in the future workplace. I need to be hired in the field of tourism and hospitality, that is to say, I should be able to use the English language with tourists and site visitors. Accordingly, being able to communicate in English is very important. I want to practise English. Frankly, teachers use Arabic not English."

Learners expressed a sense of dissatisfaction with English courses, and they did not feel any noticeable improvement in their English language communicative ability through their study in the program. Some learners improved their English communicative ability due to the training they received outside their university:

Student10:

"I have taken training courses in the English language at centers not at the university, concerning the listening skill, I began to develop; these days I can comprehend when native speakers speak in places such as downtown, especially in Bethlehem because it is the place where tourists visit the Nativity church. Also, when I watchmovies in English with no translation of subtitles, I feel I started to understand. I am happy and enthusiastic to participate and communicated with my classmates in the English language course."

We can see that the learners' views on how the university program prepares them for the future workplace are negative. The learners were not happy with the teaching methods or the content of their English language courses. Also, the students were not satisfied with the way of learning they received in their classes. The learners expressed a strong need for fostering listening, communication, and speaking skills. They indicated that these skills were overlooked.

\section{F. Results Related to Testing Used in the Courses}

Student participants mentioned that the English tests they did at the end of each course were just to pass not to measure their language competencies. The results of the interviews revealed that the learners did not take care of speaking and listening skills as parts of their courses. Student participants reported that they study to achieve better grades in the exams. 


\section{Student 9:}

"The tests learners sit for are just to get grades and compete. I and my colleges are just wanted to pass the tests. Further, these tests often include questions whose answers depend on reading, vocabulary, structures, and vocabulary. We do not have oral and listening tests."

It can be safely expressed that the testing methods of learners' progress ensured that there is a state of lack of motivation to study English; just a few learners were interested in taking extra courses to develop their speaking and communication skills. The hapless case of those learners in studying English urges us to reconsider the way of teaching English and curricula chosen to be delivered to fulfill learners' needs for learning. The next section will highlight the quantitative data related to the importance of English to learners.

\section{G. mportance of EnglishLanguage in Future Life at Work}

Table 1 below clearly shows the results related to how learners rate English in their future workplace.

\section{TABLE 1}

Means, percentages, and standard deviations of English language importance.

\begin{tabular}{|r|l|l|l|l|l|}
\hline No & Statement & N & Mean & STD & Percentage \\
\hline 1. & $\begin{array}{l}\text { English helps me to succeed in } \\
\text { external training courses delivered } \\
\text { in English. }\end{array}$ & 70 & 1.01 & $80.8 \%$ \\
\hline 2. & $\begin{array}{l}\text { English helps me to find my job } \\
\text { easier. }\end{array}$ & 70 & 3.96 & 0.95 & $79.2 \%$ \\
\hline 3. & $\begin{array}{l}\text { English is essential berceuse it is } \\
\text { the language of international } \\
\text { communication. }\end{array}$ & 3.89 & 1.06 & $77.7 \%$ \\
\hline 4. & $\begin{array}{l}\text { Learning English is important } \\
\text { because it is the language of } \\
\text { business. }\end{array}$ & 70 & 3.85 & 1.09 & $76.9 \%$ \\
\hline 5. & $\begin{array}{l}\text { English is important because it } \\
\text { gives me better chances to apply } \\
\text { for scholarships to continue my } \\
\text { graduate studies or to be involved } \\
\text { in training courses in an English- } \\
\text { speaking country. }\end{array}$ & 30.76 & 1.26 & $75.2 \%$ \\
\hline
\end{tabular}




\begin{tabular}{|r|l|l|l|l|l|}
\hline 6. & $\begin{array}{l}\text { English helps to talk with people } \\
\text { who do not speak Arabic, for } \\
\text { example, in historical sites. }\end{array}$ & 3.70 & 1.05 & $74.1 \%$ \\
\hline 7. & $\begin{array}{l}\text { The English language helps to } \\
\text { develop professional knowledge. }\end{array}$ & 70 & 3.69 & 1.18 & $73.8 \%$ \\
\hline 8. & $\begin{array}{l}\text { In the future, I will be able to learn } \\
\text { about tourists cultures. }\end{array}$ & 70 & 3.52 & 1.33 & $70.4 \%$ \\
\hline & Total score & 70 & 3.80 & 1.12 & $76.0 \%$ \\
\hline
\end{tabular}

The results of the table above show the responses of the study sample on the importance English language at work. The results indicate that the importance is very high on the first item English helps me to succeed in external training courses delivered in English, (80.8\%) whereas the rest of the items scored high ranging from (79.2\%-70.4\%). The responses on the total score were high as its percentage was $76.0 \%$. Results reveal that learners of tourism and hotel management feel: if they know how to use English effectively, it will help them in many aspects of their future jobs.

\section{Conclusion}

The results presented in the above sections showed many problems in the English language courses taught to the learners of Tourism and Hotel Management in Palestine including (1) they are not designed based on learners' needs; (2) learners are not taught well concerning their speaking and listening skills and the way the courses are delivered is old -fashion. Such a way made learners being unable to effectively and orally communicate in English; (3) the exams learners take do not make a balance between the desired skills. The tests neglect listening and speaking skills and (4) learners are not motivated by the teachers to communicate in the English language; instead, they mostly resort to translation and memos. The study also revealed that learners need to foster their English language communication skills. The English classes focus mainly on vocabulary, structures, translation of reading passages, and writing. In general, the study indicated that English language instruction was unlikely to prepare them enough for their future workplace. In a study of a similar context conducted by Musleh (2011), the Palestinian learners showed a strong positive relation between instrumentally interacting with L2 people and culture, motivation and enjoyment, awareness for needs of English. 
This study has very essential implications for management and tourism English teachers, program stakeholders, and researchers. Careful choice of English language curricula that appeal to learners' actual needs, expectations and, functionality in their future workplaces should be considered. Learners showed that English language communicative skills are important for their future workplace. Accordingly, those skills should be consolidated in those English courses. Blending ICT-based communicative activities can develop learners' communication skills. I Zulkurnain, Norafini\&Kaur, Sarjit. (2014) concluded that students are interested to join English classes that teach skills such as oral communication. In his study, Laborda (2009) revealed that web quests are important for learners of foreign languages for professional purposes, and specifically English.

Based on the needs expressed by students, English language instruction which is provided to hotel management and tourism students in Palestine should be developed. The Needs analysis should emphasize scrutinizing the English language`s real usage in areas like hotel management and tourism and how learners will use English for their future workplace. When designing the courses for these learners, learners' levels should be taken into consideration. In addition, communicative competence, and English proficiency (listening, speaking, reading, and writing), how learners can use English in their future workplace and the status of hotel management and tourism in Palestine must be implemented in any offered courses. A very important future step could be using English as a language as a tool of instruction in teaching the entire program. Fostering learners' English communication skills to fulfill their future needs at the workplace. Alternative assessment should be used instead of the summative traditional one. For instance, peer-assessment or self-assessment that motivates learners. Quantitative and qualitative future research is needed to be carried out to analyze the actual needs of undergraduate students to the English language in programs hotel management and tourism.

\section{Acknowledgment}

THE RESEARCHERS FEEL GRATEFUL TO ALL THE LEARNERS FOR THEIR VALUABLE TIME SPENT IN INTERVIEW. 


\section{References}

- Abdalla, S., \& Mohammed, H. (2016). Investigating the Application of Needs Analysis on EAP Business Administration Materials. English Language Teaching, 9(3), 74-79. https://doi.org/10.5539/elt.v9n3p74

- Abdel Ghany, S. Y., \& Abdel Latif, M. M. (2012). English language preparation of tourism and hospitality undergraduates in Egypt: Does it meet their future workplace requirements? Journal of Hospitality, Leisure, Sport \& Tourism Education, 11, 93-100

- Adiyia, B., Vanneste, D., \& Van Rompaey, A. (2016). The poverty alleviation potential of tourism employment as an off-farm activity on the local livelihoods surrounding Kibale National Park, western Uganda. Tourism and Hospitality Research, 17(1), 3451.doi:10.1177/1467358416634156

- Akyel, A. S., \& Ozek, Y. (2010). A Language Needs Analysis Research at an English Medium University in Turkey. Procedia - Social and Behavioral Sciences, 2(2), 969-975 https://doi.org/10.1016/j.sbspro.2010.03.136

- Alastal, A. A. (2012). Investigating the Academic English Language Target Needs of Undergraduates at the Faculty of Applied Science at Al-Aqsa University: Learners' Perceptions. The ASIAN ESP Journal, 8(2), 5-26. Retrieved from http://www.dt.co.kr/contents.html?article_no=2012071302010531749001

- Ali, H. I. H., \& Salih, A. R. A. (2013). Perceived Views of Language Teachers on the Use of Needs Analysis in ESP Materials Writing. English Language Teaching, 6(3), 11-19. https://doi.org/10.5539/elt.v6n3p11

- Bosuwon, T., \& Woodrow, L. (2009). Developing a Problem-Based Course Based on Need Analysis to Enhance English Reading Ability of Thai Undergraduates Learners. RELC Journal, 40(1), 42-64. https://doi.org/10.1177/0033688208101453

- CAÑAS, J. \& Pérez, L.(2015). Language needs in tourism enterprises. case study: The region of Pallars Sobirà, Catalonia, Spain, Procedia - Social and Behavioral Sciences, 212, 298-303

- Chen, I.-J., Chang, Y.-H., \& Chang, W.-H. (2016). I Learn What I Need: Needs Analysis of English Learning in Taiwan. Universal Journal of Educational Research, 4(1), 1-5. https://doi.org/10.13189/ujer.2016.040101 
- Chostelidou, D. (2010). A needs analysis approach to ESP syllabus design in Greek tertiary education: A descriptive account of learners' needs. Procedia - Social and Behavioral Sciences. 2. 4507-4512. 10.1016/j.sbspro.2010.03.721

- Choudhury, R. U.(2014). the role of culture in teaching and learning English as a foreign language. Express, an International Journal of Multi-Disciplinary Research. 1(4) :1-20

- Cravotta, J. S. (1990). English for Tourism Purposes. A new approach in the field of English for Specific Purposes. Retrieved from http://www.espfortourism.blogspot.my/2012/05/english-for-tourism-purposes.html

- Eagles, P. (2007). Global trends affecting tourism in protected areas. In R. Bushell \& P. Eagles (Eds.), Tourism in protected areas: Benefits beyond boundaries (pp. 27-43). Wallingford: CAB International

- Elsaid Mohammed, A. S., \& Nur, H. S. M. (2018). Needs Analysis in English for Academic Purposes: The Case of Teaching Assistants at the University of Khartoum. How, 25(2), 49-68. https://doi.org/https://doi.org/10.19183/ how.25.2.409

- Erazo, M., A. C., Ramírez, S., I., M., Encalada, M., A., R., Holguin , J. V. \& Zou, J., H. (2019). English language skills required by the hospitality and tourism sector in El Oro, Ecuador.Theory and Practice in Language Studies, $9($ 2):156-167 DOI: http://dx.doi.org/10.17507/tpls.0902.05

- Eslami, Z. R. (2010). Teachers’ Voice vs. Learners' Voice: A Needs Analysis Approach of English for Academic Purposes (EAP) in Iran. English Language Teaching, 3(1), 3-11. https://doi.org/10.5539/elt.v3n1p3

- Javid, C. Z. (2011). EMP Needs of Medical Undergraduates in a Saudi Context. Kashmir Journal of Language Research,14(1), 89-110

- Kacetl, J.(2018). English language teaching for learners of management of travel and tourism. SHS Web of Conferences 48, 01037. https://doi.org/10.1051/shsconf/20184801037

- Kluge, E. A. (1984). The importance of foreign language education to the hospitality industry. Journal of Nuclear Materials, 122(1-3), 354-358 
- Liton, H.(2015). ESP learners' needs related learning for the workplace: A pragmatic study for Business School Hussain. International Journal of Instruction. 8(2): 3-16. DOI: $10.12973 /$ iji.2015.821a

- Ma'an NewsAgeny. (2016, July 11). Israeli authorities confiscate antiquities from Palestinian-owned shops in Jerusalem's Old City. Retrieved from https://www.maannews.com/Content.aspx $? \mathrm{id}=772181$

- Martins, H. (2017). Revisiting Needs Analysis: A Cornerstone for Business English Courses. International Journal of English Language \& Translation Studies. 5(1), 57-63

- Mohammadi, M., \& Abdi, H. (2014). Textbook Evaluation: A Case Study. Procedia Social and Behavioral Sciences, 98, 1148-1155.doi:10.1016/j.sbspro.2014.03.528

- Musleh, R. Y. (2011). Language learning motivation: the Palestinian context. Attitudes, motivation, and orientations. Universitat de Barcelona

- Pokhilko, O.(2019). The role of foreign languages in the development of the tourism and hospitality industry in the context of globalization. Retrieved online June, 14/2019 from https://ssrn.com/abstract=3125661 or http://dx.doi.org/10.2139/ssrn.3125661

- Prachanant, N.(2012). Needs analysis on English language use in the tourism industry. Procedia - Social and Behavioral Sciences, 66: 117 - 125

- R. Nicole, "Title of paper with the only first word capitalized," J. Name Stand. Abbrev., in press.

- Razika, B.(2017).The Role of Needs Analysis in ESP Course Design Case of master one learners of Finance and International Trade Year Learners at Biskra University. Unpublished Master Thesis, Biskra University, the People's Democratic Republic of Algeria, $\quad$ Retrieved from https://pdfs.semanticscholar.org/a747/952b0a6b0f4b4749e69508536f805bb0e5e3.pdf

- Saadeh, R.( 2012,September). This week in Palestine: Experiential Tourism in Palestine. Retrieved from https://nepto.ps/experiential-tourism-in-palestine

- Semradova, I., Hubackova, S.(2013). Characteristics of language teaching for travel and tourism management learners at the Faculty of Informatics and Management. Procedia Social and Behavioral Sciences 93, $665-669$ 
- Serafini, E. J., Lake, J. B., \& Long, M. H. (2015). Needs analysis for Specialized Learner Populations: Essential Methodological Improvements. English for Specific Purposes, 40(2015), 11-26. https://doi.org/10.1016/j.esp.2015.05.002

- Sindik, J. and Božinović, N.(2013) .Importance of foreign languages for a career in tourism as perceived by learners in different years of study. Vitez-Tuzla-Zagreb-BeogradBucharest, 31(31): 1-13

- Tziora, N., Giovanis, N., \& Papacharalabous, C. (2016). The role of foreign languages in hospitality management. International Journal of Language, Translation and Intercultural Communication, 4(1), 89-97. doi:http://dx.doi.org/10.12681/ijltic.10353

- Ulla, M. B., \& Winitkun, D. (2017). Thai Learners' Linguistic Needs and Language Skills: Implications for Curriculum Development. International Journal of Instruction, 10(4), 203-220. https://doi.org/10.12973/iji.2017.10412a

- Ulum, Ö. G. (2016). ESP Need Analysis of Public Order Police Officers. International Online Journal of Education and Teaching (IJET), 4(1), 19-30. Retrieved from iojet.org/index.php/IOJET/article/view/147

- Y. Yorozu, M. Hirano, K. Oka, and Y. Tagawa, "Electron spectroscopy studies on magneto-optical media and plastic substrate interface,” IEEE Transl. J. Magn. Japan, vol. 2, pp. 740-741, August 1987 [Digests 9 ${ }^{\text {th }}$ Annual Conf. Magnetics Japan, p. 301, 1982].

- Zahedpisheh, N., Abu bakar, Z., \& Saffar, N. (2017).English for Tourism and Hospitality Purposes (ETP).English Language Teaching, 10(9): 86-94

- Zayed, J.E. (2009).The effectiveness of reflection in developing learners' oracy in English at the faculties of tourism and hospitality. Ph.D. Thesis. Egypt: Mansoura University.

- Zulkurnain, Norafini \& Kaur, Sarjit. (2014). Oral English Communication Difficulties and Coping Strategies of Diploma of Hotel Management Learners at UiTM. 3L: The Southeast Asian Journal of English Language Studies. 20. 93-112. 10.17576/3L-20142003-08

Copyright @ 2021 Dr. Hussam Qaddumi, Dr. Khaled Masood, Dr. Hassan Qaddumi, Dr. Samir Rammal, AJRSP. This is an Open-Access Article Distributed under the Terms of the Creative Commons Attribution License (CC BY NC)

Doi: doi.org/10.52132/Ajrsp.e.2021.31.3 